\title{
Isolation and characterization of the aerobic bacterial microbiota of the esophagus and its probable association with obstructive caseous lesions in green turtles (Chelonia mydas) ${ }^{1}$
}

\author{
Adriano L.S. Bindaco², Antônio Calais Júnior², Ítalo C. Almeida ${ }^{3}$, César O. Liesner², \\ Maria Rosa Ferreira ${ }^{4}$, Dirlei M. Donatele ${ }^{3}$, Gabriel D. Carvalho ${ }^{5}$ \\ and Louisiane C. Nunes ${ }^{3 *}$ (D)
}

\begin{abstract}
Bindaco A.L.S., Calais Júnior A., Almeida I.C., Liesner C.O., Ferreira M.R., Donatele D.M., Carvalho G.D. \& Nunes L.C. 2020. Isolation and characterization of the aerobic bacterial microbiota of the esophagus and its probable association with obstructive caseous lesions in green turtles (Chelonia mydas). Pesquisa Veterinária Brasileira 40(11):922-932. Centro de Ciências Agrárias e Engenharias, Universidade Federal do Espírito Santo, Alto Universitário, Alegre, ES 29500-000, Brazil. E-mail: louisianecn@gmail.com

Caseous lesions in the esophagus of green turtles (Chelonia mydas) from the coast of Brazil have been described as obstructive lesions and can lead to the death of these animals. However, their etiology remains unclear. The aim of this study was to isolate and characterize the aerobic bacterial microbiota of the esophagus of green turtles (C. mydas) from the Brazilian coast and to verify its possible participation in the etiology of caseous lesions. For this, 42 animals were used, 33 alive and healthy and 9 naturally dead that had esophageal lesions confirmed by necropsy, from Anchieta and Piúma beaches, Espírito Santo. Microbiological tests and morphological evaluation of the esophagus were performed. We isolated 14 different bacterial agents from healthy animal samples, with the prevalence of Pseudomonas aeruginosa being (36.36\%), Staphylococcus aureus (33.33\%), Aeromonas hydrophila (27.27\%), and Vibrio alginolyticus (24.24\%). In dead animals, only three distinct agents were isolated: $S$. aureus (50.00\%), A. hydrophila (25.00\%), and V. alginolyticus (25.00\%). Morphological evaluation revealed a predominance of the lesions at the gastroesophageal junction, with multifocalto-coalescent distribution, discrete intensity, and absence of obstruction. Ulcerations and caseous exudates, inflammatory infiltrates, parasitic eggs, and giant foreign body cells were also observed as well as bacterial lumps and glandular alterations, such as necrosis, adenitis, and fragments of adult parasites. There was a positive correlation between bacterial lumps and microbiological culture and a negative correlation between bacterial lumps and microbiological culture with parasites. Thus, it was noted that the esophageal aerobic microbiota of $C$. mydas was predominantly composed of Gram-negative bacteria such as $P$. aeruginosa, A. hydrophila, and V. alginolyticus, in addition to several enterobacteria and Grampositive bacteria, such as $S$. aureus. These agents are opportunists and may be involved in the etiology of caseous esophagitis in association with other pathogens as co-factors working in association or, even in a secondary way.
\end{abstract}

INDEX TERMS: Aerobic bacteria, esophagus, obstructive caseous lesions, green turtles, Chelonia mydas, microorganism; esophageal microbiota, sea turtles, wildlife animals.

\footnotetext{
${ }^{1}$ Received on July 3, 2020.

Accepted for publication on August 5, 2020.

${ }^{2}$ Graduate Program in Veterinary Science, Universidade Federal do Espírito

Santo (UFES), Alto Universitário, Alegre, ES 29500-000, Brazil.

${ }^{3}$ Centro de Ciências Agrárias e Engenharias (CCAE), Universidade Federal do Espírito Santo (UFES), Alto Universitário, Alegre, ES 29500-000, Brazil.

*Corresponding author: louisianecn@gmail.com

${ }^{4}$ Instituto de Pesquisa e Conservação Marinha (IPCMar), Avenida Beira Mar s/n, Praia da Guanabara, Anchieta, ES 29230-000, Brazil.

${ }^{5}$ Instituto Federal do Espírito Santo (IFES), Rua Augusto Costa de Oliveira 660, Piúma, ES 29285-000, Brazil.
}

RESUMO.- [Isolamento e caracterização da microbiota bacteriana aeróbia do esôfago e sua provável associação com lesões caseosas obstrutivas em tartarugas-verdes [Chelonia mydas)]. A ocorrência de lesão caseosa no esôfago de tartarugas-verdes (Chelonia mydas) da costa do Brasil tem sido descrita como de caráter obstrutivo e pode causar a morte dos animais. No entanto, sua etiologia permanece pouco esclarecida. Objetivou-se isolar e caracterizar a microbiota aeróbica esofágica das tartarugas-verdes ( $C$. mydas) da costa 
brasileira e verificar sua possível participação na etiologia das lesões caseosas. Foram utilizados 42 animais, 33 vivos e hígidos e nove mortos naturalmente que apresentavam lesão esofágica confirmada pela necropsia, provenientes de Anchieta e Piúma, Espírito Santo, nos quais foram feitos testes microbiológicos e avaliação morfológica do esôfago. Foram isolados 14 agentes bacterianos diferentes nas amostras de animais saudáveis, com prevalência de Pseudomonas aeruginosa (36,36\%), Staphylococcus aureus (33,33\%), Aeromonas hydrophila $(27,27 \%)$ e Vibrio alginolyticus $(24,24 \%)$. Nos animais mortos, foram isolados apenas três agentes distintos: S. aureus (50,00\%), A. hydrophila (25,00\%) e V. alginolyticus (25,00\%). A avaliação morfológica revelou predominância da lesão em junção gastroesofágica, com distribuição multifocal a coalescente, intensidade discreta e ausência de obstrução. Observou-se ainda ulceração e exsudato caseoso, infiltrado inflamatório, ovos de parasitos e células gigantes do tipo corpo estranho, além de grumos bacterianos e de alterações glandulares, como necrose, adenite e fragmentos de parasitos adultos. Houve correlação positiva dos grumos bacterianos com cultivo microbiológico e negativa dos grumos bacterianos e cultivo microbiológico com parasitos. Assim, nota-se que a microbiota esofágica aeróbica de $C$. mydas é constituída predominantemente por bactérias Gram-negativas como $P$. aeruginosa, $A$. hydrophila e V. alginolyticus, além de diversas enterobatérias e por Gram-positivas, como $S$. aureus. Esses agentes são oportunistas e podem estar envolvidos na etiologia da esofagite caseosa em associação a outros patógenos como co-fatores agindo em associação, ou mesmo, por via de infecção secundária.

TERMOS DE INDEXAÇÃO: Bactéria aeróbica, esôfago, lesão caseosa obstrutiva, tartaruga-verde, Chelonia mydas, microrganismo, microbiota esofágica, tartarugas marinhas, animais silvestres.

\section{INTRODUCTION}

Currently, the green turtle (Chelonia mydas) is considered by the International Union for Conservation of Nature (IUCN) as a "Vulnerable" (VU) species in Brazil and an "Endangered" (EN) species on a global scale (Seminoff 2004). Although anthropogenic action is responsible for the high mortality rate of $C$. mydas from the Brazilian coast (Gagliardi et al. 2018), viral, parasitic, fungal, and bacterial diseases also represent important causes of death for these turtles (Glazebrook\& Campbell 1990, Dominicano et al. 2017).

Several studies have suggested the involvement of the microbiota in the inflammatory lesions of different tissues in green turtles (Orós et al. 2004). In reptiles, bacterial infection can cause caseous inflammation, characterized macroscopically by a yellowish-white and friable material, and microscopically by the exudation of degranulated and degenerated heterophiles (Montali 1988).

In this context, the common occurrence of caseous esophagitis in green turtles is reported to be associated with trematode parasites and Gram-positive cocci (Santoro et al. 2007b, Calais Júnior 2015, Ribeiro et al. 2017, Jerdy et al. 2019). Santoro et al. (2007b) and Jerdy et al. (2019) proposed that bacteria have a probable origin from esophageal microbiota, while Calais Júnior (2015) suggested that they are more relevant in the development of the inflammatory response and formation of the caseous lesion; however, the genus and/or bacterial species found in these lesions were not informative for the authors.

Although the etiopathogenesis of caseous esophagitis has not been completely understood, Calais Júnior (2015) found a high prevalence $(82.22 \%)$ of the disease in the animals evaluated on the Espírito Santo coast. The same author observed that caseous exudates generated by the inflammatory processes can sometimes completely obstruct the esophageal lumen. Histologically, ulceration of the mucosa is associated with the accumulation of heterophiles (caseous), parasitic adenitis, inflammation in the lamina propria, colonies of Gram-positive bacteria, and fibrous connective tissue (Ribeiro et al. 2017).

Given this scenario, it is observed that caseous esophagitis can become obstructive and cause a decrease in food intake, cachexia, and death of animals, which can contribute to the reduction of the species population. In addition, in the literature consulted, there are no data on the esophageal microbiota of $C$. mydas, as well as the types of bacterial agents found in the inflammatory processes of the esophagus. Thus, the aim of this study was to isolate and characterizate of the aerobic bacterial microbiota of the esophagus of $C$. mydas and to demonstrate its probable involvement in the etiology of caseous esophagitis. We also performed a macro and microscopic morphological evaluation of the affected esophagus, in order to contribute to a better understanding of the disease's etiology and pathophysiology.

\section{MATERIALS AND METHODS}

Free-living turtles, alive and dead were used to obtain microbiological samples. The live animals were used to compare the microbiota and initially had the body score assessment, including only healthy individuals. The dead animals were used for the microbiological tests (postmortem time of less than 6 hours) and morphological tests (postmortem time of a maximum of 12 hours). Live and dead animals were captured by members of the Instituto de Pesquisa e Conservação Marinha, situated in Anchieta, Espírito Santo. Some corpses came from the research project "Aspectos fisiológicos e patológicos de tartarugas marinhas no litoral sul capixaba" (protocol SISBIO No. 75593-1), coordinated by Professor and Doctor Gabriel Domingos Carvalho, from "Instituto Federal de Educação, Ciência e Tecnologia do Espírito Santo” (IFES), Piúma campus.

This research protocol has an authorization for activities with scientific purpose SISBIO no 39329-4 and was approved by the "Comitê de Ética do Uso Animal" from the "Universidade Federal do Espírito Santo" (UFES), protocols 01/2018 and 16/2018.

Weight (kg), curved carapace length (CCL), curved carapace width (CCW), and the location of capture using the global positioning system (GPS) of each animal were obtained. Age was established by the parameters of CCL according to Hirth (1997). The post mortem time was assessed based on cadaveric phenomenons and was identified by the IPCMar team. Animals that presented significant cadaveric changes, such as exemple, skin and plaque detachment, enphisema, pseudomelanosis or signs of predation, were not included in the study.

Microbiological tests. In live animals, the collection of biological material was done by physical restraint of the animals, followed by the use of a mouth opener adapted from the model for small ruminants. Subsequently, a sterile swab $(15 \mathrm{~cm})$ was introduced into the esophagus of the animals and the entire mucosa of the organ was exfoliated (Fig.1A). The adapted mouth opener was able to open the maximum of the rhamphoteca (turtle's beak) in order to guarantee the introduction of the swab as caudally as possible into 
the esophagus. After removal, the swabs were individually packed in Stuart transport medium and transported under refrigeration (from 6 to $10^{\circ} \mathrm{C}$ ) to the "Laboratório de Inspeção de Produtos de Origem Animal" of the "Hospital Veterinário", "Centro de Ciências Agrárias e Engenharias" (HOVET-CCAE) of UFES (Fig.1B). In dead animals, the collection of microbiological material was made by confirmation of the caseous lesion in the esophagus (suggestive of caseous esophagitis) evaluated during necroscopic exams. Then, a sterile swab was introduced into the injured area, which was immediately stored in Stuart transport medium and sent under refrigeration to the same laboratory previously mentioned. In these specimens, microbiological culture was recommended only for the caseous area in order to isolate the bacterial agent present in the lesions. All swabs were inoculated in selective culture media for Gram-negative bacteria, such as MacConckey Agar (Enterobacteria), Pseudomonas aeromonas Selective Agar (Glutamate Starch Phenol Red Agar - GSP Agar) (Aeromonas spp./Pseudomonas spp.), and thiosulfate citrate bile salt sucrose (TCBS) agar (Vibrio spp.). To identify Gram-positive bacteria, brain heart infusion (BHI) agar was used. All media were incubated in a bacteriological oven at $37^{\circ} \mathrm{C}$ for 24 to 48 hours. Colonies growing in the BHI medium and on the selective agar (GSP, MacConckey, and TCBS) were subjected to Gram staining for classification as Gram-positive or negative. For Gram-positive bacteria, biochemical tests were performed according to Anvisa (2013) to prove the genus and consequent species of the agents. For Gram-negative bacteria, colony color and texture were also evaluated and biochemical tests were performed according to Anvisa (2013), to identify Aeromonas, Pseudomonas, and Enterobacteriaceae species and according to the Ministério da Saúde (2010) for detection of Vibrio specimens.

Macro and microscopic morphological tests. The corpses were necropsied at the IFES-Piúma or at the Setor de Patologia Animal of the HOVET-CCAE-UFES. The necropsy was performed according to the technique established by Wolke \& George (1981), with complete external examination and analysis of all organs. During the necroscopic examination, the esophagus that presented caseous exudates adhering to the mucosa was collected individually, fixed in $10 \%$ formalin, and sent to the "Laboratório de Patologia Animal" of the HOVET-CCAEUFES for macro and microscopic evaluations. Initially, each organ was photo-documented, measured (cm), and in the injured areas, the location, distribution, intensity, and size of the case were described, in addition to the esophageal lumen obstruction status according to Calais Júnior (2015). Four esophageal regions were considered: proximal region (P), medial region (M), distal region (D), and gastroesophageal junction (GJ). The tissues were processed for routine histological examination, with impregnation and inclusion in paraffin, and finally cut with a manual rotating microtome into sections of 3- $\mu$ m thickness. The resulting slides were stained with hematoxylin and eosin (HE), and GJ samples were also stained using the Periodic Acid-Schiff (PAS) technique. The samples were then analyzed using a light microscope. The variables evaluated in the microscopic description are shown in Figure 2. The data were evaluated by descriptive statistics, based on percentages (BioEstat 5.3) and for the variables of the caseous, bacterial lumps, parasites, and microbiological culture, the Spearman correlation test was used at the level of $5 \%$ probability.

\section{RESULTS}

In total, 42 specimens of Chelonia mydas were used, 33 of which were live, free-living; 84.85\% (28/33) were obtained from Praia do Além (2048'03.3"S 40³4'57.0"W) and $15.15 \%$ (5/33) from Praia Marvila (2048’47.4” S, 40³9’58.8” W), both in the municipality of Anchieta/ES and nine dead animals, $77.78 \%$ (7/9) from Piúma (2050'31.9” S, 4043'46.0” W) and $22.22 \%$ (2/9) from Anchieta (2048'03.3" S, 40³4'57.0” W).

The data on CCL, CCW, and weight of the 42 animals evaluated are shown in Table 1 . Regarding the age of the
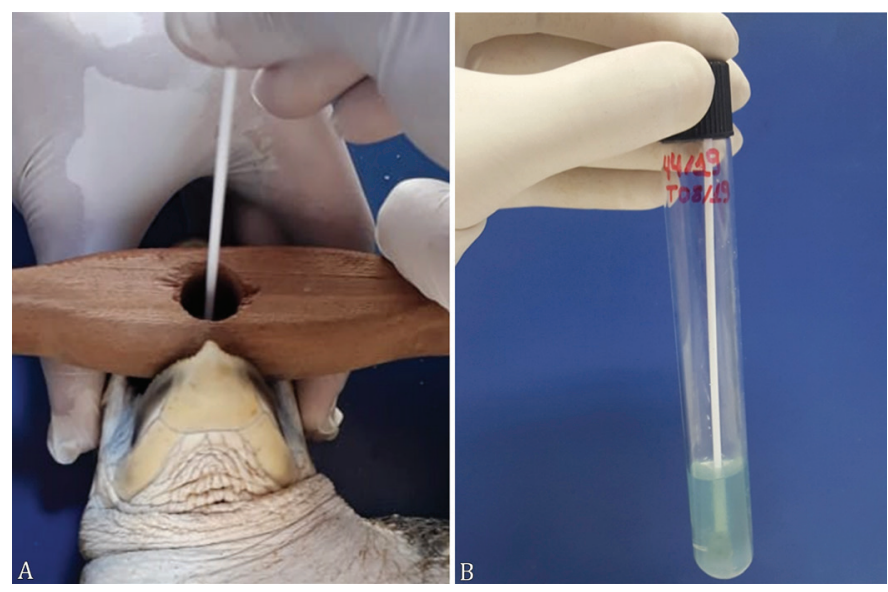

Fig.1. (A) Physical restraint and collection for microbiological samples in green turtles (Chelonia mydas) using a sterile swab and an adapted mouth opener. (B) Swab in the Stuart transport medium and identified.
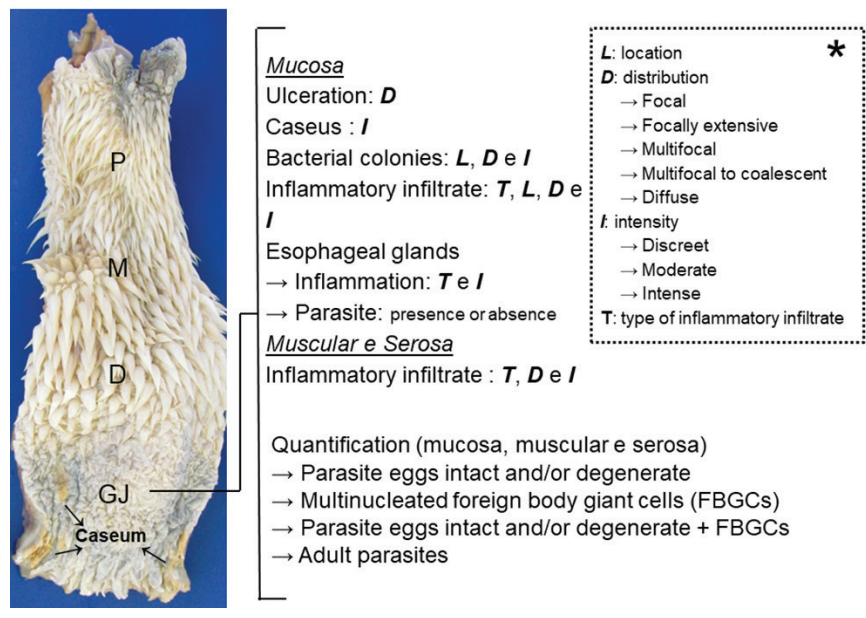

Fig.2. Variables used for the microscopic evaluation of the esophagus with caseous esophagitis of green turtles (Chelonia mydas) from the Brazilian coast from January to October 2019. The variables of location, distribution, intensity and type of inflammatory infiltrate were made according to Ackermann (2013) (asterisk).

Table 1. Average values and standard deviation of the curved carapace length (CCL), curved carapace width (CCW), and weight according to the age of the live and dead green turtles (Chelonia mydas) from the Brazilian coast from January to October 2019

\begin{tabular}{|c|c|c|c|c|c|}
\hline C. mydas & $\mathrm{N}$ & Age & $\begin{array}{l}\mathrm{CCL} \\
(\mathrm{cm}) \\
\end{array}$ & $\mathrm{CCW}(\mathrm{cm})$ & $\begin{array}{c}\text { Weigth } \\
(\mathrm{kg})\end{array}$ \\
\hline \multirow[t]{2}{*}{ Alive } & $26 / 42$ & Juvenile & $\begin{array}{c}34.89 \\
( \pm 2.63)\end{array}$ & $\begin{array}{c}32.37 \\
( \pm 3.10)\end{array}$ & $\begin{array}{c}4.76 \\
( \pm 1.07)\end{array}$ \\
\hline & $7 / 42$ & Sub-adult & $\begin{array}{c}43.04 \\
( \pm 4.22)\end{array}$ & $\begin{array}{c}39.97 \\
( \pm 4.68)\end{array}$ & $\begin{array}{c}9.19 \\
( \pm 3.00)\end{array}$ \\
\hline Dead & $9 / 42$ & Juvenile & $\begin{array}{c}34.39 \\
( \pm 1.82)\end{array}$ & $\begin{array}{c}31.73 \\
( \pm 2.13)\end{array}$ & $\begin{array}{c}4.59 \\
( \pm 1.06)\end{array}$ \\
\hline
\end{tabular}


animals, $83.33 \%$ (35/42) were juvenile, and $16.67 \%$ (7/42) were sub-adults. Among the dead animals in which it was possible to make sexual differentiation, $77.78 \%$ (7/9) male and $22.22 \%(2 / 9)$ females were analyzed.

In five corpses of $C$. mydas, no microbiological material was obtained from the lesion due to the postmortem time was greater than 6 hours, with only the morphological exams being performed on these specimens. The results microbiological culture showed the agents described in Table 2 and the biochemical tests used to identify the genus and species are shown in Table 3 and 4.

Of the nine dead animals with caseous esophagitis evaluated macroscopically, the mean esophagus length was $14.61 \mathrm{~cm} \mathrm{(} \pm$ 1.43). It was observed that $100 \%(9 / 9)$ of the lesions were located at the GJ, with $44.45 \%$ (4/9) being focal caseous exudates, 33.33\% (3/9) being multifocal-to-coalescent, and $22.22 \%(2 / 9)$ being multifocal. The intensity was discrete in $77.78 \%(7 / 9)$ and moderate in $22.22 \%$ (2/9) of the cases. The size of the caseous varied from $0.1 \mathrm{~cm}$ to $2.5 \mathrm{~cm}$, and $88.89 \%$ $(8 / 9)$ of the animals were without esophageal obstruction, while $11.11 \%$ (1/7) had partial lumen obstruction (Fig.3).

Microscopically, focal ulceration was observed in $44.45 \%$ (4/9) of the epithelia, focally extensive in $33.33 \%$ (3/9) and multifocal-to-coalescent in $22.22 \%(2 / 9)$. There was also the presence of discrete caseous in $55.55 \%$ (5/9) and moderate caseous in $44.45 \%$ (4/9) of the ulcerated areas. In the lamina propria, mononuclear inflammatory infiltrates were observed with multifocal-to-coalescent distribution in $44.45 \%$ (4/9), multifocal in $33.33 \%$ (3/9), and focal in $22.22 \%$ (2/9) of the samples. The intensity of the inflammatory infiltrate was discrete at 55.55\% (5/9) and moderate at 44.45\% (4/9) (Fig.4).

The occurrence of bacterial lumps was found in $66.67 \%$ (6/9) of the lesions, concomitant with caseous and/or ulceration. The distribution was multifocal in $50.00 \%(3 / 6)$, multifocal-to-coalescent in $33.33 \%(2 / 6)$, and focal in $16.67 \%$ $(1 / 6)$ of the samples, with $66.67 \%(4 / 6)$ and $33.33 \%(2 / 6)$ of the colonies having discrete and moderate intensities, respectively (Fig.4).

In all samples, golden brown parasite eggs (intact and degenerate) and/or multinucleated giant cells of the foreign body type were observed in the epithelium and/or lamina propria of the mucosa. There was a predominance of these structures in the lamina propria (Fig.4).

Microscopic analysis also revealed that $77.78 \%$ (7/9) of the esophageal glands had mononuclear inflammation and necrosis and thatin $57.14 \%(4 / 7)$ of the cases, the presence of adult parasite fragments was also found. In $22.22 \%(2 / 9)$ of the glands, there were no changes, while an adult parasite fragment was observed to be attached to the caseousin only $14.28 \%(1 / 9)$ of the samples (Fig.5).

Regarding the occurrence of changes in the other layers of the esophagus, only $22.22 \%(2 / 9)$ of the sampleshad an inflammatory infiltrate in the smooth musculature, discrete multifocal in both cases. No changes were observed in the serosa.

Spearman's correlation demonstrated that there was no correlation between the caseous, bacterial lumps, parasites, and microbiological culture. However, there was a positive correlation between bacterial lumps and microbiological culture $(\rho=0.16)$ and a negative correlation between bacterial lumps and parasites $(\rho=-0.16)$ and between parasites and microbiological culture $(\rho=-0.1)$.

\section{DISCUSSION}

The biometrics of the animals used in this study were similar to those of Forattini (2011), who also evaluated 31 animals from the Espírito Santo coast and found body scores from 2.6 to $20.2 \mathrm{~kg}(6.8 \pm 2.9 \mathrm{~kg})$, a CCL value ranging from 27.6 to $53.4 \mathrm{~cm}$ $(38.4 \pm 5.09 \mathrm{~cm})$ and CCW from 26.1 to $49.7 \mathrm{~cm}(34.6 \pm 4.6 \mathrm{~cm})$. This shows the high occurrence of juvenile Chelonia mydas on the coast of Espírito Santo. The predominance of individuals in the juvenile phase was also observed by Bezerra et al. (2012), as it is at this stage that the green turtle acquires herbivorous

Table 2. Aerobic bacteria isolated from the esophagus of the free-living green turtle's (Chelonia mydas) on the Brazilian coast, from June to October 2019

\begin{tabular}{|c|c|c|c|c|c|c|}
\hline \multirow{2}{*}{$\begin{array}{l}\text { Bacteria } \\
\text { isolated }\end{array}$} & \multirow{2}{*}{ Family and/or genus } & \multirow{2}{*}{ Specie } & \multicolumn{2}{|c|}{ C. mydas alive } & \multicolumn{2}{|c|}{ C. mydas dead } \\
\hline & & & Esophageal mucosa $^{a}$ & $\%^{\mathrm{b}}$ & Caseous lesion $^{c}$ & $\%^{\mathrm{d}}$ \\
\hline \multirow[t]{7}{*}{ Gram-negative } & Aeromonas & A. hydrophila & $9 / 33$ & 27.27 & $1 / 4$ & 25.00 \\
\hline & Enterobacteriaceae & Citrobacter freundii & $2 / 33$ & 6.06 & $0 / 4$ & 00.00 \\
\hline & & Escheria coli & $6 / 33$ & 18.18 & $0 / 4$ & 00.00 \\
\hline & & Proteus vulgaris & $3 / 33$ & 9.09 & $0 / 4$ & 00.00 \\
\hline & & V. fluvialis & $4 / 33$ & 12.12 & $0 / 4$ & 00.00 \\
\hline & & V. metschnikovii & $3 / 33$ & 9.09 & $0 / 4$ & 00.00 \\
\hline & & V. parahaemolyticus & $5 / 33$ & 15.15 & $0 / 4$ & 00.00 \\
\hline \multirow[t]{2}{*}{ Gram-positive } & Staphylococcus & S. aureus & $11 / 33$ & 33.33 & $2 / 4$ & 50.00 \\
\hline & & S. epidermidis & $3 / 33$ & 9.09 & $0 / 4$ & 00.00 \\
\hline
\end{tabular}

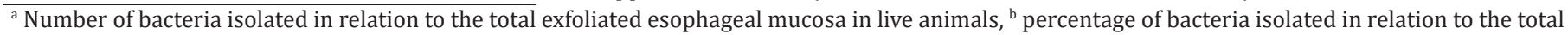

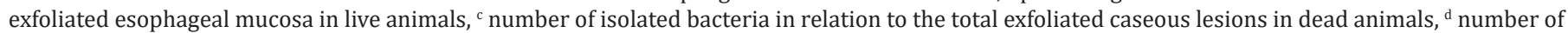
isolated bacteria in relation to the total exfoliated caseous lesions in dead animals. 


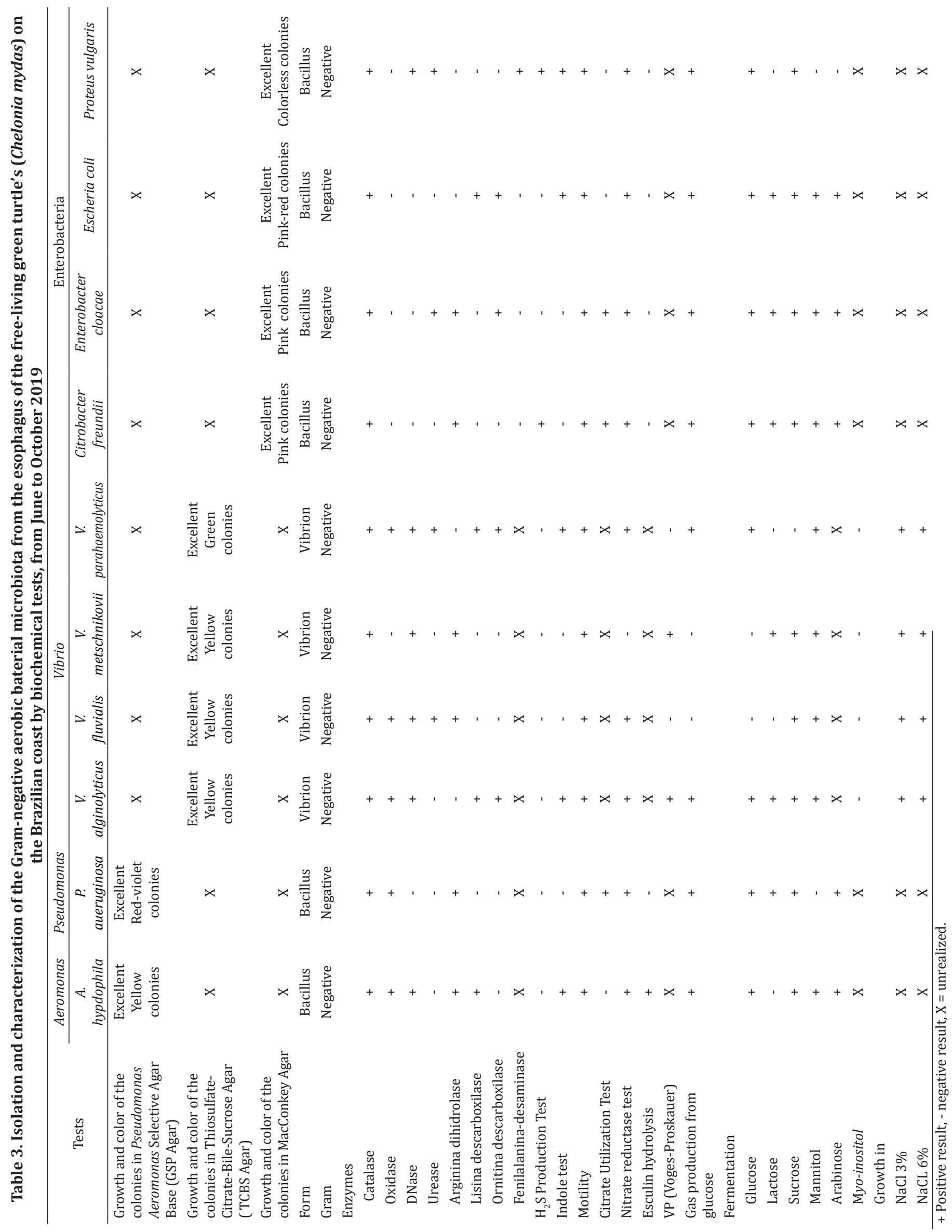


feeding habits and starts to inhabit coastal waters where marine vegetation is abundant. Thus, they are commonly observed in regions close to the coast (Bjorndal 1985).

The data from the present study revealed that the esophageal microbiota of $C$. mydas is constituted by a greater diversity of Gram-negative bacteria and by a lesser proportion of Gram-positive bacteria. The most prevalent bacteria in the esophagus of live animals were Pseudomonas aeruginosa, followed by Staphylococcus aureus, Aeromonas hydrophila and Vibrio alginolyticus. Similarly, Santoro et al. (2006) identified 21 species of Gram-negative and 8 Gram-positive agents in the nasal and cloacal regions of female green turtles in nidification, with the identification of $A$. hydrophila, Escherichia coli, $P$. aeruginosa, $S$. aureus, and V. alginolyticus. On the other hand, the same microorganisms were isolated by Orós et al. (2005) in cases of ulcerative and/or fibrinous esophagitis in C. mydas and free-living Caretta caretta, attributing the secondary infection of these agents to the trauma caused by fishing artifacts in the esophageal mucosa.

In this context, microbiological examinations of caseous esophagitis revealed bacteria that were also found in the esophagus of healthy $C$. mydas, with predominance of $S$. aureus, $A$. hydrophila, and V. alginolyticus. Thus, it is observed that the green turtle, like all reptiles, exhibits opportunistic aerobic bacterial species with pathogenic potential composing the esophageal microbiota, corroborating with Santoro et al. (2006) who revealed the opportunistic character of the isolated microorganisms in healthy $C$. mydas of their study. Also according to the same author, the presence of pathogenic bacteria in the tissues of the turtles is not synonymous with disease, and that in sea turtles the main entry points for microorganisms are injuries, mainly skin, and aspiration of sea water. However, diseases (viral and parasitic) and/or environmental conditions, for example, can affect the animal's immune system, making it more susceptible to infection by opportunistic agents that make up the healthy turtle microbiota. In this study, no traumatic injury by hooks or any other fishing device was found based on the examination of the oral cavity and no clinical signs of weakness or cachexia observed which are usually signs that may be associated with injuries caused by these artifacts, it is believed that bacterial infections in esophagitis can be triggered by several other factors, such as impairment of the immune system secondary to a concomitant underlying disease, for example.

It is worth mentioning that $A$. hydrophila, Staphylococcus spp., and V. alginolyticus are opportunistic pathogens commonly isolated from lesions in several organs of free and captive $C$. mydas. In captivity, these agents are commonly related to the development of ulcerative dermatitis and stomatitis, obstructive rhinitis, and bronchopneumonia, with stress and/or trauma as predisposing factors for infection (Glazebrook \& Campbell 1990). However, Orós et al. (2005) isolated the same agents in free-living green turtles affected by ulcerative dermatitis, pleuritis and granulomatous pneumonia, necrotizing splenitis, ulcerative esophagitis, granulomatous/necrotizing hepatitis, and myositis. In addition, Orós et al. (2004) detected the Staphylococcus genus in $22.58 \%$ of bacterial diseases in freeliving sea turtles. Thus, it can be suggested that free-living as well as captive green turtles have predisposing factors for the pathogenic action of the microbiota, such as trauma (of anthropic origin), pollution, viral diseases, and parasitism.

Table 4. Isolation and characterization of the Gram-positive aerobic baterial microbiota from the esophagus of the free-living green turtle's (Chelonia mydas) on the Brazilian coast by biochemical tests, from June to October 2019

\begin{tabular}{|c|c|c|c|c|}
\hline \multirow{2}{*}{ Tests } & \multicolumn{3}{|c|}{ Staphylococcus } & \multirow{2}{*}{$\frac{\text { Bacillus }}{\text { Bacillus spp.* }}$} \\
\hline & S. aureus & S. epidermidis & S. intermedias & \\
\hline Brain Heart Infusion Agar (BHI Agar) & Excellent & Excellent & Excellent & Excellent \\
\hline Form & Coccus & Coccus & Coccus & Bacillus \\
\hline Gram & + & + & + & + \\
\hline \multicolumn{5}{|l|}{ Enzymes } \\
\hline Catalase & + & + & + & + \\
\hline Coagulase & + & - & - & - \\
\hline Oxidase & - & - & - & - \\
\hline DNAse & + & - & + & - \\
\hline Urease & + & + & + & - \\
\hline Arginina dihidrolase & - & + & - & $X$ \\
\hline Ornitina descarboxilase & - & - & - & $\mathrm{X}$ \\
\hline $\mathrm{H}_{2} \mathrm{~S}$ Production Test & - & - & - & - \\
\hline Motility & - & - & - & + \\
\hline Indole test & - & - & - & - \\
\hline Pyrrolidonil arilamidase (PYR) & - & - & + & $\mathrm{X}$ \\
\hline \multicolumn{5}{|l|}{ Fermentation } \\
\hline Glucose & + & - & + & $\mathrm{X}$ \\
\hline Lactose & + & - & + & $\mathrm{X}$ \\
\hline Sucrose & + & + & + & $\mathrm{X}$ \\
\hline Mannitol & + & - & - & $\mathrm{X}$ \\
\hline Novobiocin & Sensitive & Sensitive & Sensitive & $X$ \\
\hline Polymyxin & Resistant & Resistant & Sensitive & $\mathrm{X}$ \\
\hline
\end{tabular}


The occurrence of Vibrio species (V. alginolyticus, V.fluvialis, $V$. metschnikovii, and V. parahaemolyticus) can be explained by the fact that these microorganisms are considered autochthonous (native) from marine and estuary environments, which inhabit these places due to availability of sodium chloride $(\mathrm{NaCl})$, salt necessary for its growth (Silveira et al. 2016). Reis et al. (2010) detected a positive result of $88.2 \%$ for Vibrio in the oral, nasal, and cloacal mucosa, and wounds of free-living juvenile C. mydas. The genus was also isolated in marine mammals, as observed by Pereira et al. (2007), who identified 17 species of Vibrio from lesions in whales, porpoises, dolphins and sea lions from the south and southeast coast of Brazil, with a higher prevalence of $V$. alginolyticus, $V$. parahaemolyticus, $V$. vulnificus and $V$. fluvialis. Thus, it is believed that because the esophagus is in constant contact with saline water, through feeding and expelling excess water, these agents may favor the esophageal mucosa.

Aeromonas and Pseudomonas are present in fresh and salt water and are considered important opportunistic pathogens in reptiles (Troiano 2018), and their presence in the esophagus of $C$. mydas can be explained by the same factors as the occurrence of Vibrio. Reis et al. (2010) observed $59.2 \%$ of Aeromonas spp. in the oral, nasal, and cloacal mucosa, and wounds of juvenile green turtles. In the same context, Santoro et al. (2006) found $25.7 \%$ of $P$. aeruginosa and $22.8 \%$ of $A$. hydrophila in the nasal cavity and cloaca of adult female $C$. mydas.

Although it occurs naturally in fresh and salt water and estuarine environments, pollution can lead to an increase in Aeromonas and affect the distribution of bacteria in the environment (Marcel et al. 2002). A. hydrophila, for example, is not native to saline waters, but domestic sewage and tributaries of rivers to the sea lead to the isolation of the agent in the marine ecosystem (Hänninen et al. 1995). In the present study, $P$. aeruginosa was the microorganism with the highest frequency of isolation in the healthy esophagus of $C$. mydas and the explanation for this may be that the agent is a strong indicator of water contamination (Guilherme et al. 2000). The coastal region, where the animals were obtained, suffers from human pressure and occupation, which makes the space subject to anthropic action and the introduction of pollution sources, such as industries, agriculture, and domestic activities, which supply chemicals and organic matter to seas. Sewage drained directly into the sea, for example, contains several impurities, which can transmit diseases, cause intoxication, and even the death of marine flora and fauna (Fernandes 2016).
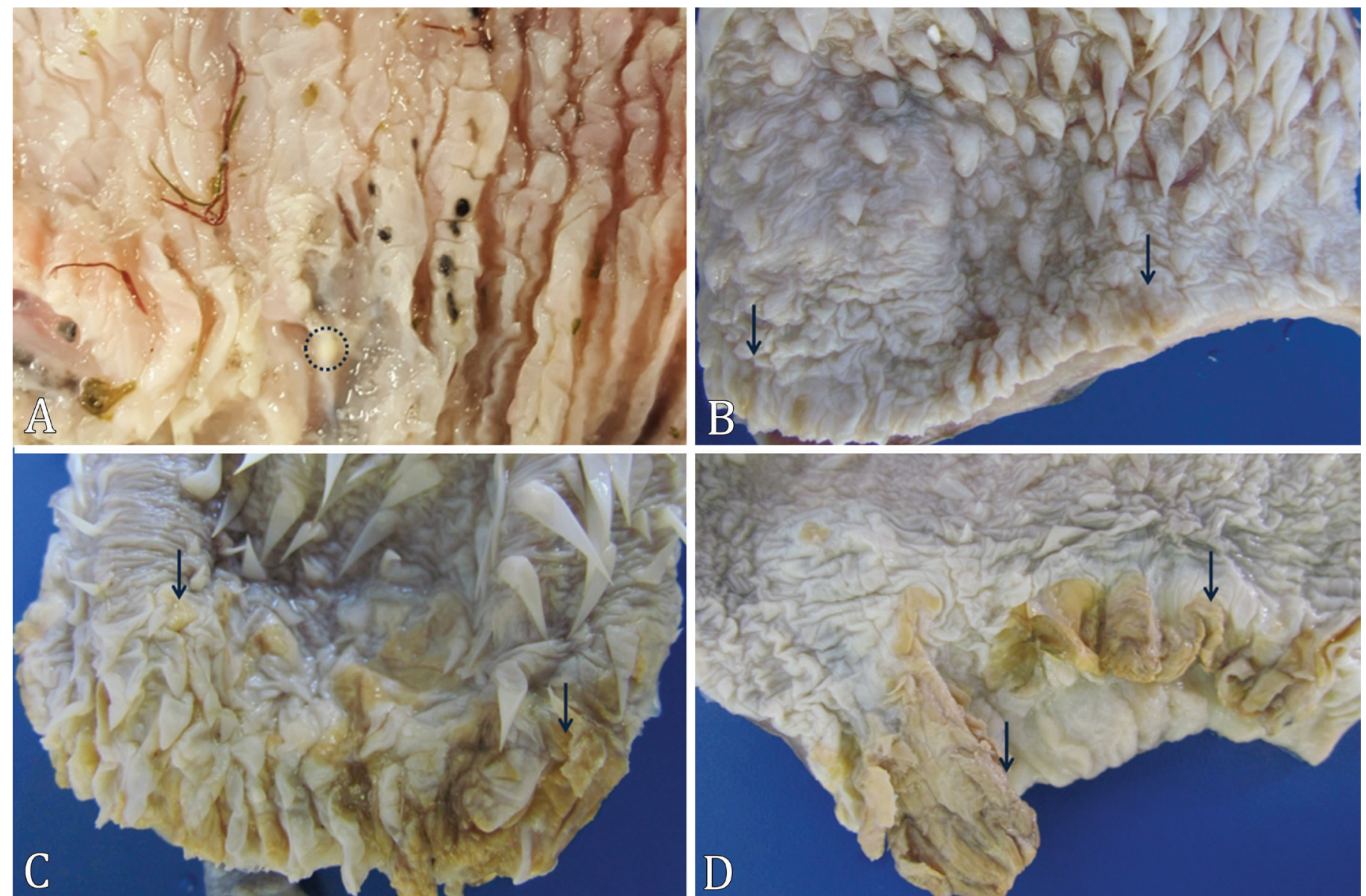

Fig.3. Caseous esophagitis in green turtles (Chelonia mydas) found naturally dead on the Brazilian coast from January to October 2019 with evidence of the caseous (dotted circle and arrows). (A) Focal distribution and discrete intensity (dotted circle). (B) Multifocal distribution and discrete intensity (arrows). (C) multifocal-to-coalescent distribution and moderate intensity (arrows). (D) multifocalto-coalescent distribution with discrete partial lumen obstruction (arrows). 
Four species of enterobacteria (Citrobacter freundii, Enterobacter cloacae, Escherichia coli, and Proteus vulgaris) were identified in the present study. The Enterobacteriaceae family includes 46 genera and 293 species and constitutes the largest and most heterogeneous family of Gram-negative bacteria (Moxley 2016), which justifies the diversity of agents of this family observed in the study. Santoro et al. (2006) found $53.1 \%$ of enterobacteria in the nasal and cloacal regions of green turtles, with isolation of E. agglomerans, E. cloacae, E. coli, K. oxytoca, K. pneumoniae, and Serratia marcescens.

Ribeiro et al. (2015) confirmed the predominance of these microorganisms in the gastrointestinal microbiota of jabuti-piranga (Chelonoidis carbonaria), with the highest

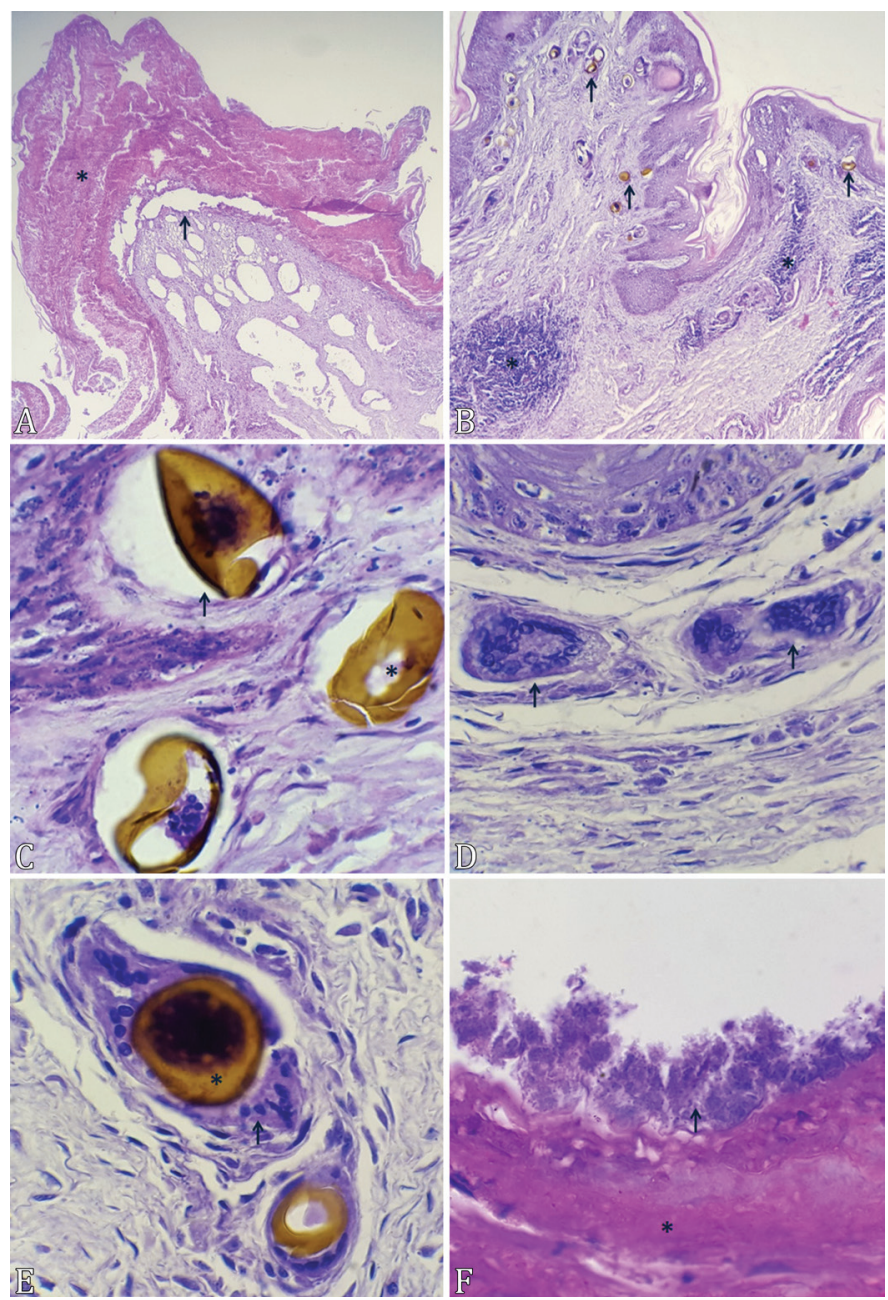

Fig.4. Caseous esophagitis in green turtles (Chelonia mydas) found naturally dead on the Brazilian coast from January to October 2019. (A) Caseous (asterisk) adhered to the ulcerated mucosa (arrow). HE, bar $=100 \mu \mathrm{m}$. (B) Mononuclear inflammatory infiltrate (asterisk) and parasite eggs (arrows) in the lamina propria. HE, bar $=100 \mu \mathrm{m}$. (C) Parasite eggs in the epithelium (arrow) and in the lamina propria (asterisk). HE, bar $=50 \mu \mathrm{m}$. (D) Multinucleated giant cells of the foreign body type in the lamina propria (arrows). HE, bar $=50 \mu \mathrm{m}$. (E) Parasite egg (asterisk) surrounded by multinucleated giant cells of the foreign body type in the lamina propria (arrow). HE, bar $=50 \mu \mathrm{m}$. (F) Bacterial colonies (arrow) adhered to the caseous (asterisk). $\mathrm{HE}, \mathrm{bar}=50 \mu \mathrm{m}$. occurrence of Escherichia coli, corroborating with the data of the present study. Enterobacteria in general, especially $E$. coli, are more commonly found in the digestive tract, because the conditions in the digestive tract such as nutrients and adequate temperature, are appropriate for their growth (Moxley 2016). In addition, microorganisms of the genus Escherichia, Citrobacter, Enterobacter and Klebsiella (coliforms) are indicators of water hygiene, especially E. coli, which is considered a strong indicator of faecal contamination (Fialho et al. 2014). With that, it can be reaffirmed that the coastal region where these animals live are subject to anthropic pollution and consequent water contamination.
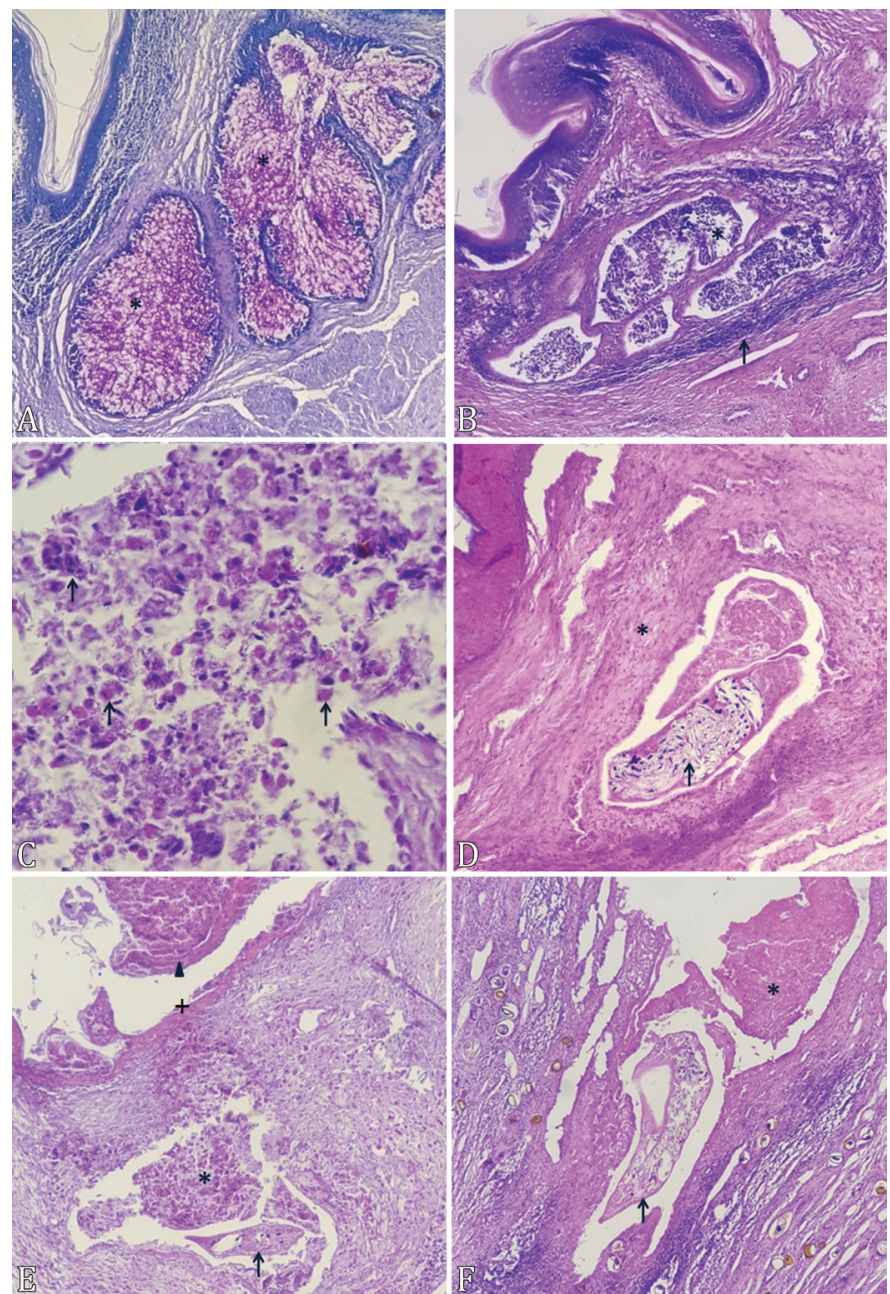

Fig.5. Esophageal glands of green turtles (Chelonia mydas) found naturally dead on the Brazilian coast from January to October 2019. (A) Gland without alterations with evidenced mucous content (asterisk). PAS, bar $=100 \mu \mathrm{m}$. (B) Periglandular (arrow) and glandular lumen with mononuclear inflammatory infiltrate and necrosis (asterisk). HE, bar $=100 \mu \mathrm{m}$ ). (C) Necrotic content in the glandular lumen (arrows). HE, bar $=50 \mu \mathrm{m}$. (D) Fragment of adult parasite (arrow) associated with glandular necrosis (asterisk). HE, bar $=100 \mu \mathrm{m}$. (E) Fragment of adult parasite (arrow) associated with glandular necrosis (asterisk), ulceration (cross), and caseous (triangle). HE, bar $=100 \mu \mathrm{m})$. (F) Presence of adult parasite fragment in ulceration area (arrow) with caseous. $\mathrm{HE}$, bar $=100 \mu \mathrm{m})$. 
Staphylococcus species are present on the skin and epithelial surfaces of all warm-blooded animals (Smeltzer \& Beenken 2016), with reports in the cloaca and nasal cavity of green turtles (Santoro et al. 2006) and oral cavity of Geoffroy's side-necked turtles (Phrynops geoffroanus) (Ferronato et al. 2009). However, to date, this agent has not yet been reported in healthy $C$. mydas esophagus. The genus is commonly involved in the development of bacterial diseases in sea turtles, with the development of lesions in various tissues and organs of a secondary and opportunistic nature. Orós et al. (2004) detected the genus in $22.58 \%$ of sea turtle diseases, including ulcerative esophagitis, granulomatous splenitis, ulcerative stomatitis, granulomatous pneumonia, and pericarditis.

Considered to be omnipresent agents in nature, Bacillus spp. inhabits soil and water, occurring on different surfaces (Stewart \& Thompson 2016). Similar to all microorganisms previously mentioned, they are part of the $C$. mydas microbiota, being isolated by Santoro et al. (2006) in the nasal cavity and cloaca of green turtles, similar to proportions isolated the present study.

In this scenario, the resident microbiota consists of the stable population of microorganisms that reside in the skin and mucous membranes of the host throughout its life. On the other hand, the transient microbiota is characterized by agents temporarily present in the tissue. In this study it was observed that the marine environment (sea water) influences the population of aerobic bacteria in the esophagus of $C$. mydas. In addition, the turtles used were free-living juveniles and are likely to travel along the Brazilian coast until they reach adulthood, when they move to the high seas (Hirth 1997). As a result, these animals inhabit different marine regions during their life cycle, and the esophagus may vary in the percentage of bacteria present, or even different genera and/or species. Therefore, it is suggested that there may be a variation in the population of bacterial agents in the esophagus of $C$. mydas, and the microbiota may be transient. However, it cannot be ruled out that the microorganisms found are part of the resident microbiota.

Regarding the morphological changes of caseous esophagitis, it was noted that all lesions were located at the GJ, similar to the findings by Calais Júnior (2015). The fact that GJ has mucus-producing glands (Calais Júnior et al. 2016), which can host trematode parasites (Calais Júnior 2015, Ribeiro et al. 2017, Santoro et al. 2007b) may justify the highest prevalence of injury in that portion. Parasites, such as Rameshwarotrema uterocrescens, are responsible for the inflammation and glandular necrosis in the esophagus of $C$. mydas (Santoro et al. 2007b).

The present study found the predominance of multifocalto-coalescent caseous lesions macroscopically, diverging from Calais Júnior (2015), who observed the prevalence of multifocal distribution. In view of the fact that the caseous develops until it completely obstructs the esophageal lumen, it is possible that the lesion starts in several foci and joins until a larger caseous mass is formed.

Histologically, caseous and ulcerations were observed in all samples evaluated, in addition to mononuclear inflammatory infiltrates. Caseous inflammation is commonly observed in reptiles, and is characterized by the exudation of heterophiles (degranulated and/or degenerate) that accumulates and macroscopically forms a yellowish-white mass of friable consistency. The heterophile of reptiles corresponds to the neutrophils of mammals and plays an important role in combating the invasion of microorganisms such as bacteria, fungi, viruses, and protozoa (Montali 1988). Mucous ulceration was also observed by Santoro et al. (2007b) and Calais Júnior (2015), and may be related to the parasite, when it is located in the lamina propria, or even to the harmful enzymes released during the inflammatory process (Montali 1988).

The mononuclear inflammatory infiltrate in the lamina propria was also observed by Calais Júnior (2015). Thus, it can be inferred that the areas of inflammation indicate a chronic process in the esophageal mucosa, since according to Pereira (2011), chronic inflammation is characterized by exudation of mononuclear cells (such as macrophages and lymphocytes), necrosis and/or degeneration and regeneration and/or repair, and changes found in the esophageal tissues evaluated.

The study in question found bacterial colonies in caseous esophagitis, a fact also confirmed by other authors (Santoro et al. 2007b, Calais Júnior 2015, Ribeiro et al. 2017, Jerdy et al. 2019). The relevant bacterial association can be explained by the fact that the heterophile plays an important role in combating bacterial invasion (Montali 1988). Calais Júnior (2015) observed Gram-positive cocci in $56.75 \%$ of caseous lesions and concluded that bacteria are important for the formation of the caseous and obstruction of the esophagus.

In addition, the bacterial occurrence was concomitant with the presence of trematode eggs in the mucosa and/or fragments of adult parasites associated with necrosis and adenitis. Adult parasites are related to acute and chronic inflammatory processes in various tissues and organs of green turtles (Stacy et al. 2010). Santoro et al. (2007a) identified parasites of the Spirorchiidae family associated with chronic inflammation in cardiovascular, gastrointestinal, and pulmonary tissues, in addition to reporting cases of secondary bacterial infection associated with the parasitic lesions. Santoro et al. (2007b), Ribeiro et al. (2017) and Jerdy et al. (2019) described that esophagitis in green turtles is due to parasitism in esophageal glands by Rameshwarotrema uterocrescens with secondary bacterial infection by Gram-positive agents. However, Calais Júnior (2015), in a study carried out on the Espírito Santo coast, observed the occurrence of four different families of trematodes (Pronocephalidae, Microscaphidae, Cladorchiidae, and Rhytidodiae) in the injured esophagus, with the family of Rameshwarotrema, one of those described, in addition to Gram-positive bacteria. These data indicate that many other parasites, in addition to the genus Rameshwarotrema, may be involved in the etiology of obstructive esophageal lesions in C. mydas.

Thus, it is believed that these parasites act as primary harmful agents in esophageal inflammation, generating a gateway for infection by opportunistic and pathogenic bacteria from the microbiota itself, or even that the lesion is of multifactorial origin, in which the parasites and bacteria act as co-factors working in association and contribute to the formation of the case and consequent obstruction.

The parasites, mainly trematodes, are common in $C$. mydas and deposit their eggs in several organs, which do not lead to the death of the green turtle. However, they can contribute to the stranding and death of juvenile animals 
(due to undeveloped immunity), or predispose to secondary diseases (Santoro et al 2007a).

In their research, Binoti et al. (2016) found intact or degenerate parasite eggs, with or without giant cells, in the spleen, lung, skeletal striated muscles, small and large intestine, kidney, salted glands, liver, stomach, heart muscle, pancreas, skin, esophagus, and adrenal glands without macroscopic lesions. The presence of the egg leads to the development of multinucleated giant cells of the foreign body type, which are formed by the fusion of macrophages, around nonimmunogenic structures such as suture threads and parasite eggs (Pereira 2011). With this, it can be suggested that the observation of only multinucleated giant cells indicates that the egg was phagocyted and eliminated from the tissue. In addition, it is believed that the presence of eggs in the tissue does not necessarily cause injury.

In this study, adenitis and glandular necrosis were also observed in the esophageal mucosa and Santoro et al. (2007b), Ribeiro et al. (2017) and Jerdy et al. (2019), associated these to the R. uterocrescens agent; however, it was not possible to identify the species of the parasites, limiting themselves to classifying the agents as trematodes.

Thus, the location of intraglandular trematodes can justify the presence of eggs in the lamina propria. However, there are no data in the literature about the biological cycle of the parasites found in the esophagus of $C$. mydas; thus, it is not possible to exactly state the route taken by the parasitic agent to reachthe esophageal gland as well as the way in which they deposit their eggs.

On the other hand, the data obtained in this study by statistical tests also showed that when there is an increase in bacteria, either by observation of the bacteria by microscopy or by the number of isolated agents, there is a decrease in the parasitic load. However, the negative correlation observed was very weak and may be related to the chronicity of the lesion and the fact that the parasite is no longer observed in the tissue.

\section{CONCLUSION}

The esophageal microbiota of Chelonia mydas is predominantly composed of Gram-negative bacteria such as Pseudomonas aeruginosa, Aeromonas hydrophila, and Vibrio alginolyticus, in addition to several enterobacteria and Gram-positive agents, with the highest prevalence being Staphylococcus aureus. These agents are opportunists and may be involved in the etiology of caseous esophagitis in association with other pathogens as co-factors working in association or, even in a secondary way.

Conflict of interest statement.- The authors have no competing interests.

\section{REFERENCES}

Ackermann M.R. 2013. Inflamação e cicatrização, p.309-310. In: Zachary J.F. \& McGavin M.D. (Eds), Bases da Patologia Veterinária. 5ª ed. Elsevier, Rio de Janeiro.

Anvisa 2013. Módulo 6, Detecção e Identificação de Bactérias de Importância Médica. Agência Nacional De Vigilância a Sanitária, Brasília, DF. Available at <https://www20.anvisa.gov.br/segurancadopaciente/index.php/ publicacoes/item/deteccao-e-identificacao-de-bacterias-de-importanciamedica> Accessed on Feb. 20, 2020.

Bezerra M.F., Lacerda L.D., Costa B.G.B. \& Lima E.H.S.M. 2012. Mercury in these a turtle Chelonia mydas (Linnaeus, 1958) from Ceará coast, NE
Brazil. An. Acad. Bras. Ciênc. 84(1):123-128. <https://dx.doi.org/10.1590/ S0001-37652012005000002>

Binoti E., Gomes M.C., Calais Júnior A., Werneck M.R., Martins I.V.F. \& Boeloni J.N. 2016. Helminthfauna of Chelonia mydas (Linnaeus, 1758) in the south of Espírito Santo State in Brazil. J. Helminthol. 53(2):195-199. <https:// dx.doi.org/10.1515/helmin-2016-0012>

Bjorndal K.A. 1985. Nutritional ecology of sea turtles. Copeia 1985 (3):736751. <https://dx.doi.org/10.2307/1444767>

Calais Júnior A. 2015. Caracterização histomorfológica e histoquímica de esôfagos de tartarugas verdes (Chelonia mydas) com e sem alterações no litoral do Espírito Santo. Master's Thesis, Universidade Federal do Espírito Santo, Alegre.

Calais Júnior A., David J.A.O. \& Nunes L.C. 2016. Caracterização morfológica do esôfago de tartarugas-verdes (Chelonia mydas). Arq. Bras. Med. Vet. Zootec. 68(1):127-135. <https://dx.doi.org/10.1590/1678-4162-8548>

Dominicano I.G., Domit C. \& Bracarense A.P.F.R.L. 2017. The green turtle Chelonia mydas as a marine and coastal environmental sentinels: anthropogenic activities and diseases. Semina, Ciênc. Agrárias 38(5):3417-3434. <https:// dx.doi.org/10.5433/1679-0359.2017v38n5p3417>

Fernandes L. 2016. Ocupação da zona costeira, p.43. In: Gerling C., Ranieri C., Fernandes L., Gouveia M.T.J \& Rocha V. (Eds), Manual de Ecossistemas Marinhos e Costeiros para Educadores. Comunnicar, São Paulo.

Ferronato B.O., Marques T.S., Souza F.L, Verdade L.M. \& Matushima E.R. 2009. Oral bacterial microbiota and traumatic injuries of freeranging Phrynops geoffroanus (Testudines, Chelidae) in southeastern Brazil. Phyllomedusa 8(1):19-25. <https://dx.doi.org/10.11606/issn.2316-9079.v8i1p19-25>

Fialho R.C.J., Calvet R.M., Pereira M.M.G., Costa A.P.R., Monte A.M., Santos Y.F.M. \& Muratori C.S. 2014. Ocorrência de enterobactérias em sistemas de carcinicultura marinha do litoral do Piauí, Brasil. Revta Bras. Med. Vet. 36(1):60-64.

Forattini J.G. 2011. Concentrações de testosterona plasmática em uma população juvenil de Chelonia mydas no efluente industrial de uma companhia siderúrgica, Vitória, Espírito Santo. Master's Thesis, Universidade Vila Velha, Vila Velha. 47p.

Gagliardi T.R., Lopes T.C. \& Serafim T.Z. 2018. Interação de tartarugas marinhas e a pesca no Brasil: uma revisão da literatura. Arq. Ciênc. Mar 51(1):101124. <https://dx.doi.org/10.32360/acmar.v51i1.20354>

Glazebrook J.S. \& Campbell R.S.F. 1990. A survey of the diseases of marine turtles in northern Australia. I. Farmed turtles. Dis. Aquat. Organ. 9(1):8395. <https://dx.doi.org/10.3354/dao009083>

Guilherme E.F.M., Silva J.A.M. \& Otto S.S. 2000. Pseudomonas aeruginosa, como indicador de contaminação hídrica/Pseudomonas aeruginosa as na indicator of water contamination. Hig. Aliment. 14(76):43-47.

Hirth H.F. 1997. Synopsis of the Biological Data on the Green Turtle, Chelonia mydas (Linnaeus, 1758). Fish and Wildlife Service, U.S. 97(1):1-120.

Jerdy H., Werneck M., Veloso R., Baldassin P., Netto H.G., Barbosa C., Bianchia M., Ribeiro R.B. \& Carvalho E.C.Q. 2019. Fatal Rameshwarotrema uterocrescens infection with ulcerative esophagitis and intravascular dissemination in green turtles. Int. J. Parasitol. Parasites Wildl. 9:281-284.<https://dx.doi. org/10.1016/j.ijppaw.2019.06.006><PMid:31289721>

Marcel K.A., Antoinette A.A. \& Mireille D. 2002. Isolation and characterization of Aeromonas species from an eutrophic tropical estuary. Mar. Pollut. Bull. 44(12):1341-1344.<https://dx.doi.org/10.1016/s0025-326x(02)00143-1> $<$ PMid:12523537>

Ministério da Saúde 2010. Manual integrado de vigilância epidemiológica da cólera. Available at <http://bvsms.saude.gov.br/bvs/publicacoes/ manual_integrado_vigilancia_colera2ed.pdf> Accessed on Feb. 20, 2020.

Montali R.J. 1988. Comparative pathology of inflammation in the higher vertebrates (reptiles, birds and mammals). J. Comp Pathol. 99(1):1-26. <https://dx.doi.org/10.1016/0021-9975(88)90101-6><PMid:3062051> 
Moxley R. 2016. Família Enterobacteriaceae, p.55-57. In: Mcvey D.S., Kennedy M. \& Chengappa M.M. (Eds), Microbiologia Veterinária. $3^{\text {a }}$ ed. Guanabara Koogan, Rio de Janeiro.

Orós J., Calabuig P. \& Déniz S. 2004. Digestive pathology of sea turtles stranded in the Canary Islands between 1993 and 2001. Vet. Rec. 155(6):169-174. <https://dx.doi.org/10.1136/vr.155.6.169>

Orós J., Torrent A., Calabuig P. \& Déniz S. 2005. Diseases and causes of mortality among sea turtles stranded in the Canary Islands, Spain (1998-2001). Dis. Aquat. Organ. 63(1):13-24. <https://dx.doi.org/10.3354/dao063013> <PMid:15759796>

Pereira C.S., Amorim S.D., Santos A.F.M., Siciliano S., Moreno I.M.B., Ott P.H. \& Rodrigues D.P. 2007. Vibrio spp. isolados de mamíferos marinhos capturados na spp. isolados de mamíferos marinhos capturados na região litorânea do sudeste ao sul do Brasil região litorânea do sudeste ao sul do Brasil. Pesq. Vet. Bras. 27(2):81-83. <https://dx.doi.org/10.1590/S0100736X2007000200005>

Pereira F.E.L. 2011. Inflamações, p.195-213. In: Brasileiro Filho G. (Ed.), Patologia Bogliolo. 8ª ed. Guanabara Koogan, Rio de Janeiro.

Reis E.C., Pereira C.S., Rodrigues D.P., Secco H.K.C., Lima M.L., Rennó B. \& Siciliano S. 2010. Condição de saúde das tartarugas marinhas do litoral centro norte do estado do Rio de Janeiro, Brasil: avaliação sobre a presença de agentes bacterianos, fibropapilomatose e interação com resíduos antropogênicos. Oecol. Aust. 14(3):756-765.<https://dx.doi.org/10.4257/ oeco.2010.1403.11>

Ribeiro M.M., Táparo C.T., Makatu M.Y., Destro M.M., Araújo Júnior E.C. \& Gargia S.M.VA.D. 2015. Análise da microbiota gastrointestinal de Chelonoidis provenientes de cativeiro da região noroeste de São Paulo. Vet. Zootec. 22(2):295-301.

Ribeiro R.B., Jerdy H., Werneck M.R., Goldberg D.W., Bianchi M. \& Carvalho E.C.Q. 2017. Parasitic ulcerous caseousgastroesophagitis associated with Rameshwarotrema uterocrescens Rao, 1975 (Digenea: Pronocephalidae) in a Juvenile Green Turtle [Chelonia mydas, Linnaeus 1758 (Testudines: Cheloniidae)]: a case report. J. Parasitol. 103(3):292-294.<https://dx.doi. org/10.1645/16-106> <PMid:28122470>
Santoro M., Hernández G., Caballero M. \& García F. 2006. Aerobic bacterial flora of nesting green turtles (Chelonia mydas) from Tortuguero National Park, Costa Rica. J. Zoo Wildl. Med. 37(4):549-552. <https://dx.doi. org/10.1638/05-118.1> <PMid:17315444>

Santoro M., Morales J.A \& Rodrígues-ortiz B. 2007a. Spirorchiidiosis (Digenea: Spirorchiidae) and lesions associated with parasites in Caribbean green turtles (Chelonia mydas). Vet. Rec. 161(14):482-486. <https://dx.doi. org/10.1136/vr.161.14.482> <PMid:17921440>

Santoro M., Stacy B. \& Greiner E.C. 2007b. Rameshwarotrema uterocrescens trematode parasitism of the oesophageal glands in green sea turtles (Chelonia mydas). Vet. Rec. 160(2):59-60. <https://dx.doi.org/10.1136/ vr.160.2.59><PMid:17220526>

Seminoff J.A. 2004. Chelonia mydas. The IUCN Red List of Threatened Species 2004: e.T4615A11037468. Southwest Fisheries Science Center, U.S.

Silveira D.R., Milan C., Rosa J.V. \& Timm C.D. 2016. Fatores de patogenicidade de Vibrio spp. de importância em doenças transmitidas por alimentos. Arq. Inst. Biológico, São Paulo, 83:e1252013.<https://dx.doi.org/10.1590/18081657001252013>

Smeltzer M.S. \& Beenken K.E. 2016 Staphylococcus. In: Mcvey D.S., Kennedy M. \& Chengappa M.M. (Eds), Microbiologia Veterinária. $3^{\mathrm{a}}$ ed. Guanabara Koogan, Rio de Janeiro.

Stacy B.A., Foley A.M., Greiner E.C., Herbst L.H., Bolten A.B., Klein P.A., Manire C.A. \& Jacobson E.R. 2010. Spirorchiidiasis in stranded loggerhead Caretta caretta and green turtles Chelonia mydas in Florida (USA): host pathology and significance. Dis. Aquat. Organ. 89(3):237-239. <https://dx.doi. org/10.3354/dao02195><PMid:20481091>

Stewart G.G \& Thompson B.M. 2016. Bacillus, p.211-216. In: Mcvey D.S., Kennedy M. \& Chengappa M.M. (Eds), Microbiologia Veterinarians. $3^{\mathrm{a}}$ ed. Guanabara Koogan, Rio de Janeiro.

Troiano J.C. 2018. Doenças dos Répteis. MedVet, São Paulo, p.193-209.

Wolke R.E \& George A. 1981. Sea Turtle Necropsy Manual. NOAA Technical Memorandum NMFS SEFC-24, Panama City, p.16-20. 